\title{
Componential Analysis of Meaning of the Word "Melihat" In Javanese and English Language
}

\author{
Mamik Nugraheni \\ SMA Tunas Patria Ungaran \\ mamiknugraheni@gmail.com
}

\begin{abstract}
It is a qualitative descriptive study that attempts to depict the componential meaning of the word 'melihat' or 'to see' in Javanese and English and the element of context that may influence the word choice in both languages. By using documentation as method of data collection, it is found that there are many different words having the same meaning to say 'melihat' in both languages while those words means that anyone doing activities of 'melihat'. In addition, the aspects of intensity, target, distance, and connotative features influence the word choice in either Javanese or English.
\end{abstract}

Keywords: Componential Meaning, Melihat, Javanese, English

\begin{abstract}
Abstrak
Ini adalah penelitian deskriptif kualitatif yang berusaha untuk menggambarkan makna komponen pada kata 'melihat' dalam bahasa Jawa dan bahasa Inggris serta meneliti elemen konteks yang mempengaruhi diksi pada kedua bahasa tersebut. dengan menggunakan dokumentasi sebagai metode pengumpulan data, penelitian membuktikan bahwa ada banyak kata yang berbeda yang memiliki kesamaan makna untuk mengungkapkan kata 'melihat' pada kedua bahasa. Sedangkan, kata-kata tersebut memiliki arti bahwa pelaku melakukan aktifitas 'melihat'. Di samping itu, aspek intensitas, target, jarak, dan ciri-ciri konotatif mempengaruhi diksi pada bahasa Jawa maupun bahasa Inggris.
\end{abstract}

Kata Kunci: Makna Komponental, Melihat, Bahasa Jawa, Bahasa Inggris 


\section{Introduction}

Every language has different system that characterizes its use, likewise Javanese and English. To say 'melihat', for instance, there are many words can be chosen to express speaker's idea. Javanese, as a tool of communication for Javanese generally, have many ways to say that words, such as:

1. Udin lagi ndelok TV.

2. Nek mlaku ndelengi dalan!

3. Rina ngamati gaweane koncone sing lagi digarap.

Those three words have different forms but similar meaning; expressing 'melihat'. In English, the same thing can be found, for example:

1. My brother is watching TV.

2. Look at the street!

3. The teacher observes the student assignments.

From the above examples, different words which have the same meaning in the sentences called synonymy. The words 'begin', 'start', 'sofa', 'settee', 'adore', and 'worship' are just a few of hundreds words that seem to be frequently interchangeable without loss of meaning. However, they are truly synonymous that they always mean the same and can be substituted one another (Carthy, 1990: 16). Therefore, we need to know the meaning of the word deeply before using it. Sometimes we are confused to understand words we do not know the meanings exactly. Not only in English, in Javanese have we also found the synonymy that shows the richness of word meaning.

Derived from that phenomenon, the writer is interested in conducting the analysis of componential meaning of the word between two languages by addressing following research questions.

1. What are the components of meaning that differentiate between one word to another in Javanese synonym of the word 'ndeleng'?

REGISTER, VOL. 2, No. 1, JUNE 2009 
2. What are the components of meaning that differentiate between one word to another in English synonym of the word 'to see?

3. What element of context that may influence the word choice in Javanese and in English?

\section{Semantics}

Semantics is the technical term used to refer to the study of meaning. It is a part of linguistics that not only includes meaning but also development and changing (Palmer, 1981: 1). According to Fromkin (1985: 201), it is a study of linguistic meaning of words, phrase, and sentences.

\section{Lexical Relation}

In the discussion of meaning, there are many parts to be elaborated; one of them is lexical relation. According to Saeed (1997: 36), there are eight lexical fields in the lexical relation.

1. Synonyms, which are different phonological words which have the same or very similar meaning.

2. Antonym (opposition), words which are opposite in meaning.

3. Homonymy, unrelated senses of the same phonological words.

4. Polysemy

5. Hyponym

6. Meronymy

7. Member collection

8. Portion-mas

\section{Componential Analysis}

When people contemplate communication in foreign language, they often reach for dictionary since it provides meanings for words of given language 
and labels for concepts that speakers wish to discuss. Then, how does the meaning of words in a sentence contribute to the meaning of sentence? Componential analysis of this kind can reveal a relation among words from the same semantic domain, such as kinship terms. It attempts to describe the systematic ways in which words are alike or unlike ( Carthy, 1990: 92). He (1990: 92) states that it is also the way of looking at the meaning of words, describing words in terms of shared and non-shared semantic features, these features themselves being only expressible as words.

Semantic componential analysis is based on the similarities among set of words. The goal of semantic feature (componential) analysis is to discover a set of features that make up the meanings of words. In this analysis, the lexical relation of synonym is important because words related to the ways of sharing features. The purpose of semantic field analysis is to arrive at meaning shared by a group of words in a domain. That, all the words within the field related to each other, yet differs in details, which are captured in the analysis.

The componential analysis can be applied satisfactorily only in certain well-defined semantic domains. In many cases, it is difficult to define the elementary "features" which distinguish the meaning of a word from that of similar ones. For instance, the word 'chair' has some similar meaning with bench, davenport, and sofa. But, it is not exactly the same; there are some features differentiate them. It is described as follows.

$\begin{array}{lcccc} & \text { Wood substance } & \text { Foot } & \text { Expensive } & \text { Hand } \\ \text { Bench } & + & + & - & - \\ \text { Chair } & + & + & - & - \\ \text { Davenport } & - & + & - & -\end{array}$


Sofa $\pm$ $+$ $+$ $+$

From the table, the distinctive features of those words are the substance, shape, and the price of the chairs.

\section{Research Methodology}

It is a descriptive qualitative research that is used to depict the phenomenon of the using of the word 'melihat', as object of the study, in Javanese and English. Since it is a literary study, the writer uses documentation as data collection method that is taken from primary and secondary books i.e.:

1. Introduction to Theoretical Linguistics (1997)

2. Introducing English Semantics (1978)

3. Semantics (1981)

4. Kamus Bahasa Jawa (2002)

5. Bausastra Jawa-Indonesia (1957)

6. The New Grolier Webster International Dictionary of the English Language (1974)

7. An Introduction to Psycholinguistics (1992)

8. Semantik Leksikal (2001)

\section{Discussion}

In this research, the writer tries to use the most appropriate word to the context; but still, it seems there is no one-to-one relationship between Javanese and English words. In order to make the research more practical and understandable, the whole data are presented in the table 1.1.

REGISTER, VOL. 2, No. 1, JUNE 2009 
Those data, then, are analyzed descriptively using the semantic field of the word 'melihat' or 'to see'. They are:

1. Intensity

It shows duration of seeing.

2. Target

It means any object used for the purpose of seeing.

3. Crossbeam

Crossbeam refers to something that delays activity of seeing.

4. Distance

Distance shows an interval or space between two objects. It means the distance between the doer and the target of seeing.

5. Connotative

It means implication of a word or phrase in addition to its literal meaning.

To clear the discussion, the data are scrutinized in the Table 1.2. and 1.3.

REGISTER, VOL. 2, No. 1, JUNE 2009 
Table 1.1. Data Presentation

\begin{tabular}{|c|c|c|c|c|c|}
\hline \multirow{2}{*}{ No. } & \multirow{2}{*}{ Javanese } & \multirow{2}{*}{ English } & \multirow{2}{*}{ Meaning } & \multicolumn{2}{|c|}{ Sentence } \\
\hline & & & & Javanese & English \\
\hline 1 & Mandeng, Kamitenggengen & Behold & to look at with attention, to see & Kowe kok mandeng aku wae, ngopo? & Why do you behold of me in that way? \\
\hline \multirow{2}{*}{2} & Mentheleng, Mendelik, & \multirow{2}{*}{$\begin{array}{l}\text { Stare, } \\
\text { look at }\end{array}$} & \multirow{2}{*}{ to look with eyes fixed wide open } & \multirow{2}{*}{ Bocah kuwi nangis amarga dipenthelengi bapake. } & \multirow{2}{*}{$\begin{array}{l}\text { That child is crying because his father stares at } \\
\text { him }\end{array}$} \\
\hline & Mlolo, Mlorok, Mlelek & & & & \\
\hline \multirow{2}{*}{3} & \multirow{2}{*}{ Mlilik, Nglirik } & Look at & to employ one's vision, to direct the eyes toward an object. & \multirow{2}{*}{$\begin{array}{l}\text { Bocah kuwi miliki dolanan sing dipajang ono } \\
\text { toko. }\end{array}$} & \multirow{2}{*}{ The child descrys the toys in the store. } \\
\hline & & Descry & to espy, to see or behold from a distance & & \\
\hline 4 & Ndeleng & Contemplate & to look at or view with continued attention. & Ibu-ibu podo ndeleng carane nggawe kue. & The women contemplate how to make a cake. \\
\hline 5 & Ndelok & See & to perceive by the eye, to look at or behold & Ayo podho ndelok wayang ana alun-alun. & Let's see the Javanese-puppet show in the town. \\
\hline 6 & Namati, Nyawang & Regard & to look up on or think of in a particular way & $\begin{array}{l}\text { Wong lanang kuwi namati peta pirang-pirang } \\
\text { jam. }\end{array}$ & That man regarded the map for hours. \\
\hline 7 & Nonton & Watch & to be or continue without sleeping & Udin lagi nonton TV. & Udin is watching television. \\
\hline \multirow{2}{*}{8} & \multirow{2}{*}{ Weruh } & Glance & to look quickly or briefly & \multirow{2}{*}{ Ibuku weruh gaweane masku. } & \multirow{2}{*}{ My mother glimpse at my brother's work. } \\
\hline & & Glimpse & a quick, passing view or look, a brief appearance & & \\
\hline 9 & Ngulatke & Gaze at & $\begin{array}{l}\text { to look steadily, intently, to look with eagerness or } \\
\text { curiosity. }\end{array}$ & Wong kuwi ngulatke sapa wae sing teka. & That guy gazes at the guest. \\
\hline \multirow{3}{*}{10} & \multirow{3}{*}{ Nginjen } & Peep & to look through a small aperture of rom a hidden place & \multirow{3}{*}{ Ojo seneng ngjinjen, ora apik! } & \multirow{3}{*}{ Don't peep, it is not good! } \\
\hline & & Peek & to look quickly or furtively & & \\
\hline & & Peer & to look narrowly, as in the effort to discern clearly & & \\
\hline
\end{tabular}

REGISTER, VOL. 2, No. 1, JUNE 2009 
Table 1.2. Componential analysis of meaning of Javanese words

\begin{tabular}{|c|l|c|c|c|c|c|}
\hline \multirow{2}{*}{ No } & \multicolumn{1}{|c|}{$\begin{array}{c}\text { Activities } \\
\text { of seeing }\end{array}$} & Intensity & Target & Crossbeam & $\begin{array}{c}\text { The } \\
\text { Distance }\end{array}$ & $\begin{array}{c}\text { Connotative } \\
\text { features }\end{array}$ \\
\cline { 2 - 7 } & A & B & C & D & E \\
\hline 2 & Mandeng & + & Near & - & + & + \\
\hline 3 & Mlelek & - & Near & - & + & - \\
\hline 4 & Mlilik & + & Near & - & + & $+/-$ \\
\hline 5 & Nglirik & $+/-$ & Near & - & - & $+/-$ \\
\hline 6 & Mendelik & - & Near & - & + & - \\
\hline 7 & Kamitenggengen & + & Near/far & - & $+/-$ & + \\
\hline 8 & Ndeleng & + & Near & - & + & + \\
\hline 9 & Ndelok & + & Near/far & - & $+/-$ & + \\
\hline 10 & Namati & + & Near & - & + & + \\
\hline 11 & Nyawang & + & Near/far & - & $+/-$ & + \\
\hline 12 & Mlolo & $+/-$ & Near & - & + & - \\
\hline 13 & Mlorok & - & Near & - & + & - \\
\hline 14 & Nonton & + & Near/far & - & $+/-$ & + \\
\hline 15 & Weruh & - & Near/far & - & $+/-$ & + \\
\hline 16 & Ngulatke & + & Near & - & + & + \\
\hline 17 & Nginjen & $+/-$ & Near & + & + & - \\
\hline
\end{tabular}

Table 1.3. Componential analysis of meaning of English Words

\begin{tabular}{|c|l|c|c|c|c|c|}
\hline \multirow{2}{*}{ No } & \multirow{2}{*}{$\begin{array}{c}\text { Activities } \\
\text { of seeing }\end{array}$} & Intensity & Target & Crossbeam & The Distance & $\begin{array}{c}\text { Connotative } \\
\text { features }\end{array}$ \\
\cline { 3 - 7 } & A & B & C & D & E \\
\hline 1 & Behold & + & Near & - & - & + \\
\hline 2 & Contemplate & - & Near & - & - & + \\
\hline 3 & Descry & + & Far & - & + & + \\
\hline 4 & Glance & + & Near/far & - & - & + \\
\hline 5 & Gaze & + & Near & - & - & + \\
\hline 6 & Glimpse & + & Near & - & - & + \\
\hline 7 & Look at & + & Near & - & - & + \\
\hline 8 & Look out & + & Near & - & - & + \\
\hline
\end{tabular}




\begin{tabular}{|c|l|c|c|c|c|c|}
9 & Peek & - & Near/far & + & + & $+/-$ \\
\hline 10 & Peep & - & Near & + & + & - \\
\hline 11 & Peer & - & Near & + & + & - \\
\hline 12 & Regard & + & Near & - & - & + \\
\hline 13 & See & + & Near & - & - & + \\
\hline 14 & Stare & - & Near & - & - & + \\
\hline 15 & Watch & + & Near/far & - & - & + \\
\hline
\end{tabular}

\section{Ambivalence}

In the table, it is seen that there are words have two signs i.e. (+) and (-) called ambivalence. It means that there are two meanings or purposes from the words depending on the context. Furthermore, such words are elaborated below, based on the componential analysis of meaning.

\section{Intensity}

In Javanese, 'nglirik' and 'nginjen' have two signs of positive and negative. 'Nglirik' can be high if the doer wants to make long seeing activities. However, it is also can be low if the doer makes it short or just a moment. 'Nginjen' also has the same thing; the doer can make it either long or short. All of activities depend on the doer. In English, ther is no ambivalence of the intensity.

\section{Target}

In Javanese, 'kamitenggengen', 'ndelok', 'nyawang', and 'weruh' have near and far object of seeing. In English, 'glance', 'peek', and 'watch' have near and far object. It means that the object can be shown as far as the eyes see.

\section{Distance}


The word 'ndelok', 'nyawang', 'nonton', 'weruh', and 'kamitenggengen' in Javanese are used in far or near distance. It means that the doer can be seen at near or far objects.

4. Connotative features

The word 'mlilik' is the one which has both signs. It shows that 'mlilik' has two connotative features of meaning. In English, we can see that 'peek' also has both signs of connotative features.

Actually, there are still many activities of seeing that can interpret the meaning. Like 'ngeker', it is inlcude of the activities of seeing. But it is not discussed in this research because it needs a tool when such an activity done. What discussed here are the activities of 'seeing' with bare activities without any tools. Here, the writer used a free translation in each word from the obtained data by trying to use the most appropriate word to the context.

\section{Conclusion}

From the study conducted by the writer, there are many different words having the same meaning to say 'melihat' in both languages. Meanwhile, those words mean that anyone does activities of 'melihat'. In addition, the aspects of intensity, target, distance, and connotative features influence the word choice in either Javanese or English.

REGISTER, VOL. 2, No. 1, JUNE 2009 


\section{References}

Carthy, Michael. 1990. Vocabulary. Oxford New York: Oxford University Press.

Palmer, F.R. 1981. Semantics. Sydney. Cambridge University Press.

Saeed, John I. 1997. Semantics. Blackwell.

Fromkin, Victoria. 1985. An Introduction to Linguistics. Sydney: Halt Rinehart and Winston.

REGISTER, VOL. 2, No. 1, JUNE 2009 